\title{
Land cover in the Northern Forest Complex of Myanmar: new insights for conservation
}

\author{
Swen C. Renner, John H. Rappole, Peter Leimgruber, Daniel S. Kelly, Nay Myo Shwe, Thein Aung and \\ Myint Aung
}

\begin{abstract}
We classified land cover in the Northern Forest Complex in Myanmar using satellite imagery (MODIS/NDVI) and field surveys carried out in 2001, 2004 and 2005. Using Landsat TM/ETM+ images from 1991 and 1999 we determined deforestation rates. The c. $22,000 \mathrm{~km}^{2}$ Northern Forest Complex, including the Hkakabo Razi National Park in northern Kachin State, is characterized by tropical to subtropical pristine forests with low human impact. The area studied, which includes land beyond the boundaries of Hkakabo Razi National Park, is of special conservation importance because it provides a refuge for many rare plant and animal species. Less than $1.4 \%$ of the area is affected by humans (excluding hunting) and deforestation rates are low at $<0.01 \%$ annually. We observed several bird and mammal
\end{abstract}

species that are considered threatened elsewhere. Based on our data, those of previous surveys, and the fact that $>10$ new vertebrate species have been described in the region since 1999, it is likely there are still undescribed vertebrate species to be discovered. We recommend extending the boundaries of Hkakabo Razi National Park to the south and west, connecting it to Hpongkan Razi Wildlife Sanctuary, and/or adding an additional sanctuary in the Naung Mung area, to protect the vast yet still pristine rainforest habitats that are home to many of the most important aspects of the region's biodiversity.

Keywords Deforestation, Himalaya, land cover classification, Myanmar, Northern Forest Complex, South-east Asia, tropical forest.

\section{Introduction}

Extensive pristine areas with little human impact are critical for the long-term survival of many threatened and endemic species, but such areas are rare (Gascon et al., 2000; Myers et al., 2000; Achard et al., 2002). Southeast Asia has almost no contiguous, extensive primary habitats remaining (Reich et al., 1997; Mayaux et al., 1998; Myers et al., 2000; Riitters et al., 2000; Achard et al., 2002; Leimgruber et al., 2003). In Myanmar, however, with the exception of the central dry zone, much of the country's natural forest cover remains (Tordoff et al., 2004; Leimgruber et al., 2005). Except for the Irrawaddy (Ayayerwaddy) delta, which was deforested during the British colonial period, deforestation is comparatively low (Tordoff et al., 2004; Leimgruber et al., 2005). The Northern Forest Complex of Myanmar, which

Swen C. Renner (Corresponding author), John H. Rappole, Peter Leimgruber and Daniel S. Kelly Conservation \& Research Center, National Zoological Park, Smithsonian Institution, 1500 Remount Road, Front Royal, VA 22630 USA.E-mail renners@si.edu

Nay Myo Shew, Thein Aung and Myint Aung Nature and Wildlife Conservation Division, Department of Forestry, West Gyogone Insein, Yangon, Union of Myanmar.

Received 31 May 2005. Revision requested 21 September 2005 Accepted 4 January 2006 contains Hkakabo Razi National Park, lies in a unique biogeographical position between Eurasia, the Indian subcontinent and South-east Asia. This has resulted in high levels of species richness and endemism, and the occurrence of many rare species. New taxa are still being discovered in this region, demonstrating the importance of further exploration and conservation action (Rappole et al., in press), especially in areas such as the Alungdung Valley in the heart of Hkakabo Razi National Park, an area almost completely undisturbed by humans (Rappole et al., in press; Rappole et al., 2005; Cincotta et al., 2000).

Existing maps for the region date from the British colonial period. During surveys of bird communities in 2001, 2004 and 2005 in and around Hkakabo Razi National Park (Rappole et al., in press; Rappole et al., 2005) we collected information to update these maps, including current coverage of major habitats and effects of recent land-use changes. In the work reported here we used the now standard tool of habitat mapping using satellite imagery (Leimgruber et al., 2005) to address four interrelated research and conservation objectives: (1) create a land cover map for the Northern Forest Complex of Myanmar, (2) determine overall forest loss during 1990-2000, (3) develop a conservation profile for the area, and (4) develop suggestions for conservation strategies. 


\section{Study Area}

The study area stretches east from Putao to the border with the Chinese province of Yunnan and north to the northern tip of Myanmar in the Himalayas (Fig. 1). This Northern Forest Complex includes all of Hkakabo Razi National Park and parts of Hpongkan Razi Wildlife Sanctuary. Rabinowitz (2003) included in the Northern Forest Complex areas south of Putao to Myitkyina (incorporating the Hukang Tiger Reserve and the Bumhpa Bum Wildlife Sanctuary). However, we define the area as in Fig. 1 (c. 22,000 $\mathrm{km}^{2}$ ), excluding the areas south of Putao where the habitats and associated species are markedly different from areas further north. The Complex is in the transition zone between three major biodiversity hotspots (Myers et al., 2000; Conservation International, 2004) and includes the Eastern Himalayas Endemic Bird Area that supports 19 restricted-range bird species of which 10 are globally threatened (Stattersfield et al., 1998; BirdLife International, 2003).

The highest peak is the 5,881 m Mount Hkakabo Razi and the lowest elevations are on the Putao plains at $c$. $420 \mathrm{~m}$. Vegetation types change along a steep elevation gradient and include subtropical rainforest, temperate rainforest, mixed deciduous forest, Pinus-Rhododendron forests and alpine meadows. Agriculture occurs at lower elevations in the larger valleys. Indigenous people use the forest, mainly along or near major rivers, paths or villages, for hunting and trapping of small to mediumsized birds and mammals, collecting edible and medicinal plants, logging, and collection of thatching material. In addition, fishing is common in the larger rivers. We observed that timber extraction occurs mainly in and around the larger villages (Putao, Naung Mung) and up to $2 \mathrm{~km}$ into adjacent valleys but does not appear to occur in the smaller villages in the Nam Tamai valley further than c. $0.5 \mathrm{~km}$ from settlements.

\section{Methods}

\section{Land cover classification}

For the land cover classification we used Normalized Difference in Vegetation Index (NDVI) data acquired by the Moderate Resolution Imaging Spectroradiometer (MODIS) of NASA's Terra satellite. Although MODIS NDVI data has a coarser spatial resolution $(250 \mathrm{~m})$ than Landsat satellite data $(30 \mathrm{~m})$, its greater temporal resolution (one image per day for MODIS versus one every 21 days for Landsat) is better for mapping seasonally changing habitats in areas with heavy cloud cover such as northern Myanmar. We used a MODIS NDVI image for February 2004 (EOS Data Gateway, 2005), co-registered it to NASA's orthorectified Geocover (Tucker et al., 2004), and used supervised classification to produce a land cover map with seven categories: pristine lowland forest (with $\geqslant 60 \%$ forest cover); highland Pinus-Rhododendron forest; tundra and highland steppe; bushy and shrubby vegetation; developed areas, including settlements, rice paddies and fallow areas; rocks and boulders (including all areas without vegetation); snow and ice fields.

In 2001, 2004 and 2005 SCR, JHR and NMS collected data on vegetation and land cover and use in pristine forests and any secondary vegetation at various locations (Fig. 1; Table 1). We surveyed localities and obtained a total of 79 points, with a global positioning system, used for truthing the land cover classification, during 2001 (7 weeks in February-March), 2004 (5 weeks in February-March) and 2005 (3 weeks in September). Some of these locations were visited in more then one year. Points within the same land cover category and located within $100 \mathrm{~m}$ of each other were combined for the purposes of the land cover classification, giving a total of 38 localities to which we subsequently assigned a land cover category (Table 1) and where we carried out surveys (see below). We ensured that at least $60 \mathrm{~m}$ around each point was homogenous habitat, but also noted other habitat within $200 \mathrm{~m}$ of the point (Table 1). We walked a total of 239, 126 and $106 \mathrm{~km}$ in 2001, 2004 and 2005, respectively, from Naung Mung northwards, and survey localities were at c. $15 \mathrm{~km}$ intervals (Fig. 1). In 2001 and 2004 there was an additional $100 \mathrm{~km}$ of driving, with surveys, from Putao via Babaw and URing-Ga to Naung Mung (routes are indicated approximately in Fig. 1).

\section{Surveys}

Birds were captured at each locality using 20 mist nets (12* $2.6 \mathrm{~m}, 36 \mathrm{~mm}$ mesh). We set nets at about noon and closed them the following day at about the same time in 2001, but sampled localities for at least three nights in 2004 and 2005 (720/240/144 hours of 20 mist nets set in 2001/2004/2005 respectively). Additionally, whenever possible, we identified birds observed whilst walking. All individuals were identified to species, and aged and sexed if possible. Most individuals were released immediately after identification and photographic documentation, although representative specimens were kept, particularly for those birds showing obvious differences from field guide descriptions (Robson, 2000). From the latter, we prepared skin specimens for comparison with museum material, and to form the basis of a reference collection at the Myanmar Forestry Department (251 skins, 226 tissue samples, 74 alcohol and 25 skeleton specimens have been prepared out of c. 1,200 captures). We compared specimens of particular interest with the bird collections 


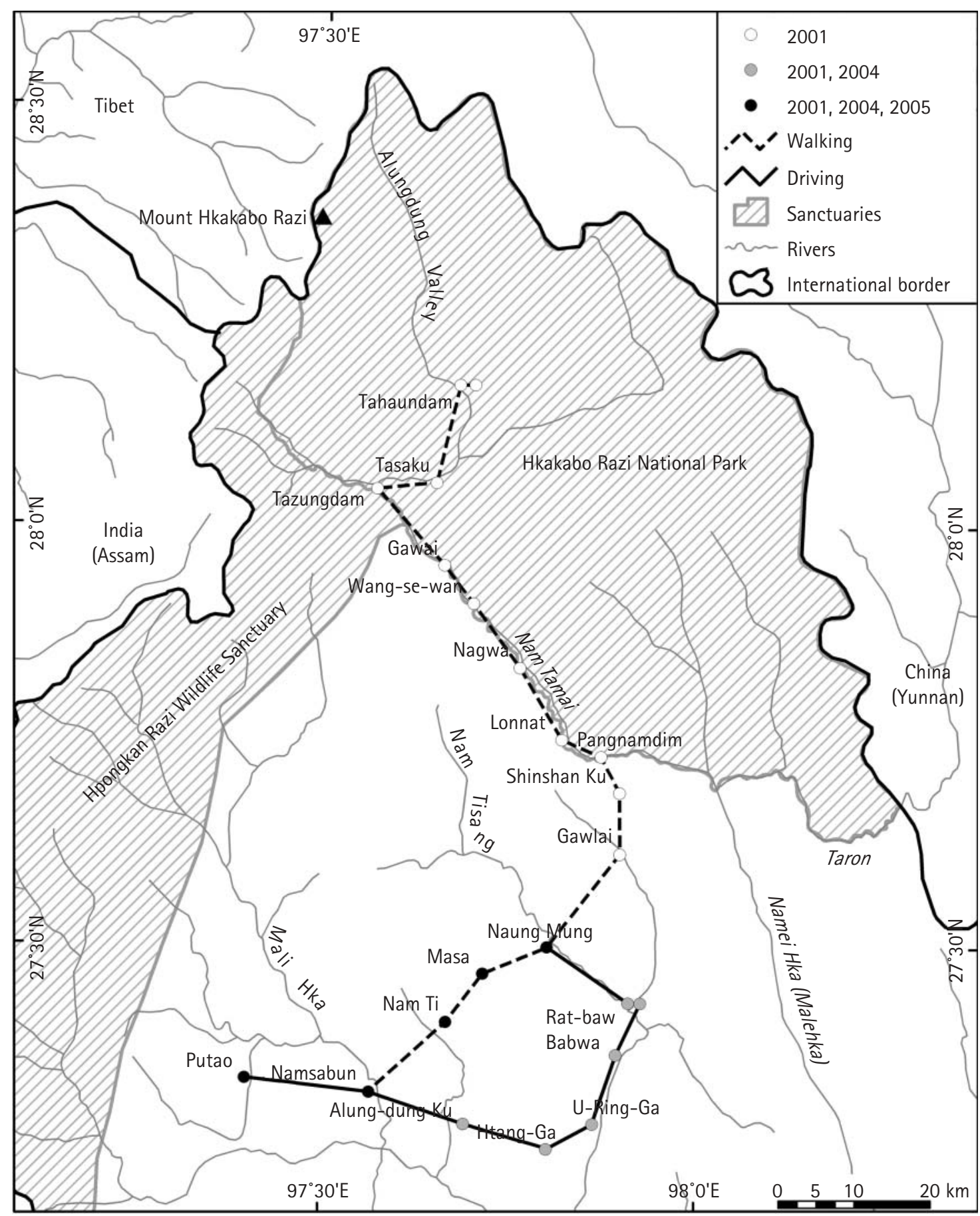

Fig. 1 The Northern Forest Complex of Myanmar, with the locations of Hkakabo Razi National Park and Hpongkan Razi Wildlife Sanctuary, major rivers and settlements, and the routes and localities surveyed in 2001, 2004 and 2005.

at The Natural History Museum (Tring, UK), Museum für Naturkunde (Berlin, Germany), The Academy of Natural Sciences (Philadelphia, USA), American Museum of Natural History (New York, USA), California Academy of Sciences (San Francisco, USA) and US National Museum of Natural History (Washington, DC, USA). Detailed information on new taxa is published or available elsewhere (Rappole et al., 2005; Rappole et al., in press; S.C. Renner et al., unpubl. data) and only a summary is presented here. 


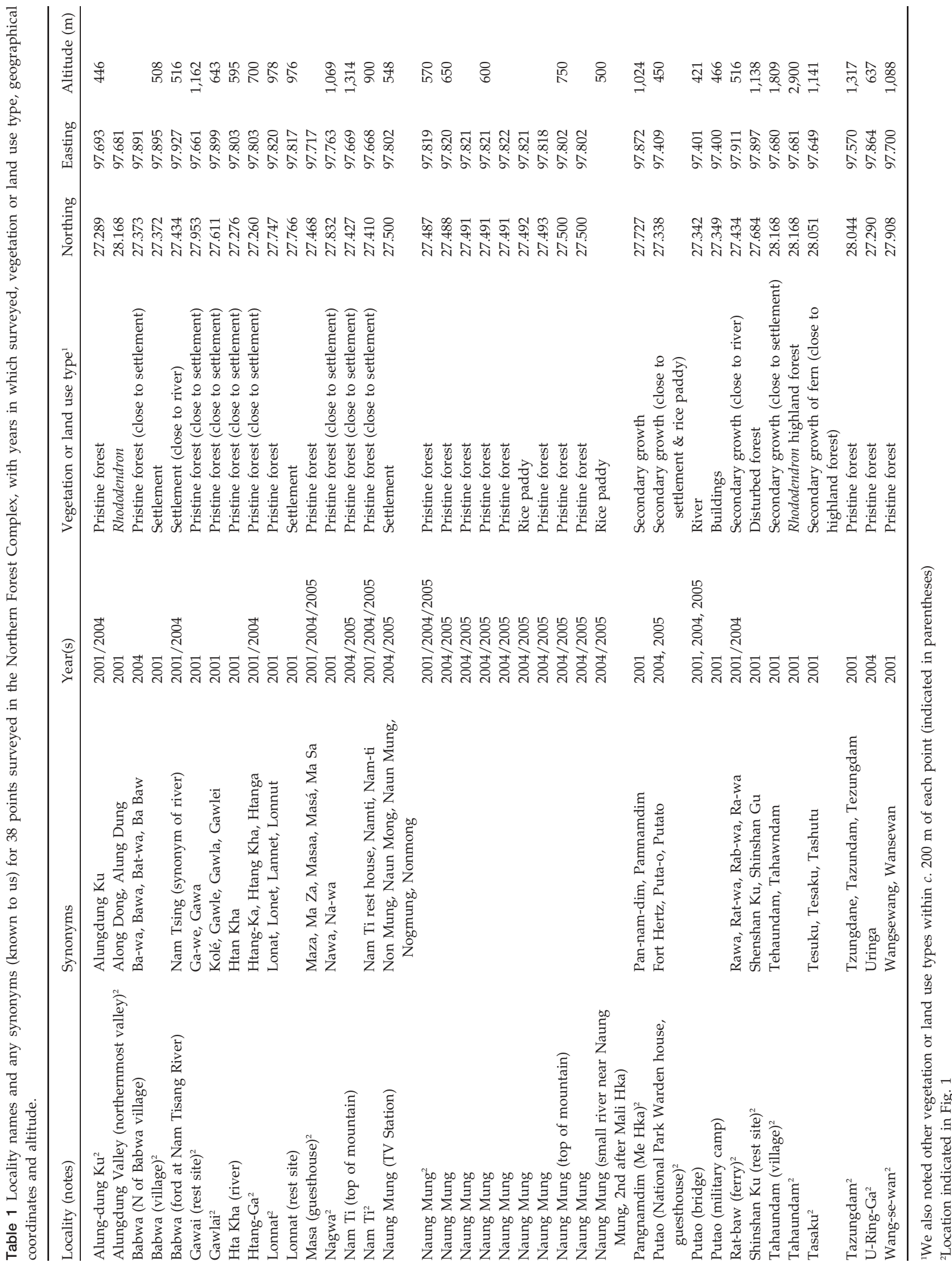




\section{Miscellaneous observations}

In addition to collecting data on birds and habitats we obtained data on the human population, including demography and socioeconomics. We asked the villagers about their economic needs and the most pressing local environmental issues, and also approximate population and household numbers, food sources, hunting activities, and striking species of special interest or concern, e.g. leopard Panthera pardus, elephant Elephas maximus, red panda Ailurus fulgens, gibbon Bunipithecus hoolock, gaur Bos gaurus, and tiger Panthera tigris. For these observations we relied on translations of conversations with villagers (in $\mathrm{Li} \mathrm{Su}$, Tibetan, or Karaung) by our guides. We present here a descriptive summary of this miscellaneous data.

\section{Deforestation}

To determine deforestation between 1991 and 1999 we used two images, one acquired by the Landsat Thematic Mapper for 1991 and one by the Enhanced Thematic Mapper for 1999. By combining the images we delineated forest areas with significant changes in multispectral reflectance between 1991 and 1999. This analysis was restricted to areas south of Tahaundam (Fig. 1) because we were unable to acquire cloud-free Landsat images for the northern part of the study area.

\section{Results}

\section{Land cover}

The plains of Putao and Naung Mung and to a lesser extent the valleys of the Mali Hka (Hka = river), Nam Tamai, Namai Hka and Kasaung Hka are used for agriculture. Agriculture shifts from rice paddies in areas $<1,000 \mathrm{~m}$ altitude to wheat and corn in areas $>1,000 \mathrm{~m}$. The most common land cover is pristine forest, which

Table 2 Area and percentages of land cover types in the Northern Forest Complex (Fig. 2) mapped using satellite images taken in 2004 (see text for further details).

\begin{tabular}{lcr}
\hline Land cover & Area $\left(\mathrm{km}^{2}\right)$ & $\%$ \\
\hline Developed areas (settlements \& agriculture) & 290 & 1 \\
Rocks \& boulders & 1,270 & 6 \\
Snow \& ice fields & 2,020 & 9 \\
Tundra \& highland steppe & 2,190 & 10 \\
Highland Pinus-Rhododendron temperate forest & 2,100 & 10 \\
Bushy \& shrubby vegetation (secondary & 2,730 & 13 \\
$\quad$ regrowth, including ferns) & & \\
Pristine lowland forest* & 11,090 & 51 \\
Total & 21,730 & 100 \\
\hline
\end{tabular}

*Including evergreen and subtropical forests. covers $>50 \%$ of the area (Table 2). Only a small area $(14 \%)$ is influenced by human use, including settlements, rice paddies, and secondary regrowth. The latter usually follows the slash-and-burn agriculture traditional in the region. Only c. $1 \%$ of the area is currently under use, and the remaining 11-12\% (bushy and shrubby vegetation; Table 2) are abandoned areas in various stages of succession. In total $>80 \%$ of the Northern Forest Complex can be assigned to natural or low impact areas. Hunting also occurs in the area but it is not clear how much impact this has beyond the villages. In Nam $\mathrm{Ti}$ we found one hunter setting snare traps $c .3 \mathrm{~km}$ from the next settlement close to the main path from Nam Ti to Masa, and some of our local guides claimed to hunt regularly using crossbows and snares, but typically close to villages.

\section{Deforestation}

Deforestation is a marginal phenomenon in the Northern Forest Complex and $<1 \%$ of the total area changed between 1991 and 1999. The southern areas below 1,000 m lost a total area of 515 ha in this 8-year period. All deforestation took place in the populated valleys of the Mali Hka and Nam Tamai, and the flood plains of Putao and Naung Mung. We also detected some deforestation of high altitude areas, but these areas are characterized by natural bush and shrub vegetation as well as tundra and have spectral signatures similar to early successional vegetation following logging, and they were probably deforested before 1991. These habitat types appear to have declined in some areas, probably because of escaped fires from shifting agricultural practices in the valleys. These vegetation types are particularly prevalent on south- and east-facing slopes immediately below the elevation at which PinusRhododendron forests grow; the natural vegetation of these slopes have been replaced by ferns. However, these land cover changes took place before 1991.

\section{Miscellaneous observations}

Human impact is concentrated in river valleys of highlands $(>1,000 \mathrm{~m})$ north of Tasaku and Tazungdam (Fig. 1) and the large river plains (Putao, Naung Mung). The bottoms and slopes of the valleys are burnt and subsequently used for agriculture, usually wheat in the north and corn in the south. In most cases entire hillsides are deforested, but only areas near the valley floor and settlements are actively used for agriculture; the rest are covered by secondary growth. Settlements in the river valleys are generally small, consisting of a few households. Most of the human population is concentrated in the Mali Hka valley and the Putao plains, with 


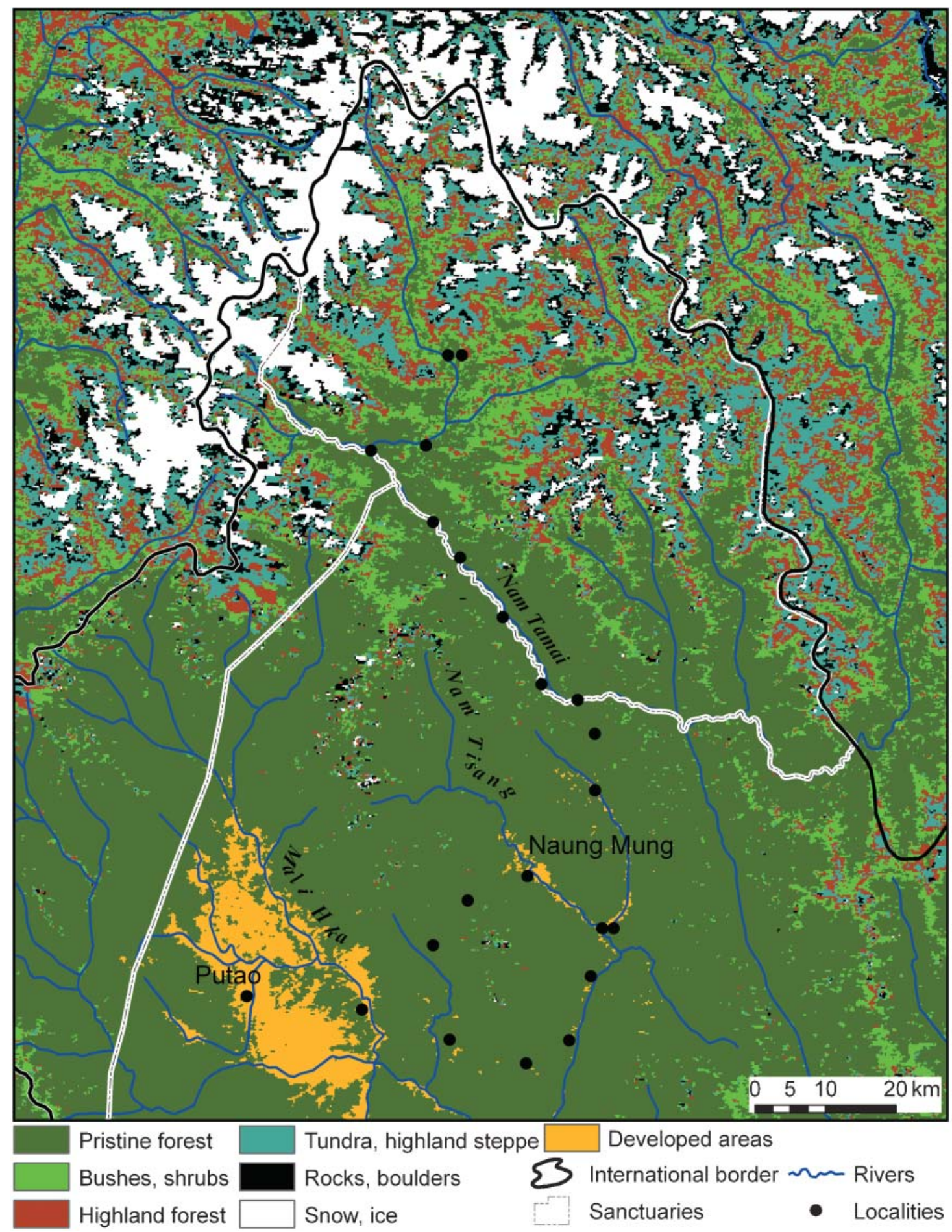

Fig. 2 Land cover classification of the Northern Forest Complex of Myanmar using MODIS/NDVI images from 2004 (see text for further details).

an overall population in the Northern Forest Complex of c. 8,000 (6,000 in Putao, 500 in Naung Mung, 1,500 scattered in the valleys). Settlements and agriculture are moving up into the mountains in the southern parts of the Alungdung valley, with loss of pristine forest.

\section{Discussion}

\section{Land cover}

Lack of forest on mountain hillsides bordering river valleys indicates how far even relatively low-level 
human activities are reaching into this remote region, a problem exemplified by the extensive secondary growth found on steep slopes in the northern part of the Northern Forest Complex (north of Gawai above 1,500 m, especially at Tahaundam). Examination of sites at similar elevations elsewhere in Hkakabo Razi National Park revealed that typically dense forests occur near villages if the area has not been cleared or burned. However, slopes near villages are often covered by fern and other low, secondary growth vegetation, presumably resulting from the frequent burning used to prepare agricultural fields. The fires, normally set at the valley bottoms, easily get out of control, causing devastation of entire neighbouring slopes. We observed one such fire on 24 February 2001 that apparently escaped from a low elevation burn close to a village (at c. 1,700 m elevation) and within a few hours moved upslope to mixed deciduous-coniferous forest at c. $2,500 \mathrm{~m}$.

\section{Deforestation}

Our estimate of deforestation is conservative because it does not include open areas that were logged prior to 1990. However, overall annual deforestation in the Northern Forest Complex is low, nearly undetectable, and well below rates reported for other parts of Southeast Asia (FAO, 2003; Leimgruber et al., 2005). For example, Myanmar and Thailand have annual deforestation rates of $0.3 \%$ (Leimgruber et al., 2005) and $0.7 \%$ (FAO, 2003) respectively. The lack of logging in the Northern Forest Complex is a consequence of its remoteness, the low human population and the lack of ready access to markets. The limited access to the region is illustrated by the difficulties of transportation: goods from the Northern Forest Complex are transported from Putao to Myitkyina by road for at least 5 days, or by air. Hence most products from the Northern Forest Complex are either for the local Putao market or, if they can command a good price, for China. For example, cane grown in the Naung Mung/Rat-baw area for furniture was a profitable good for sale to the Chinese market in 2005 and 2006 (S. Renner, pers. obs.). The cane was transported first by pack animals or truck to Putao and then by truck to Myitkyina. However, the area north and east of Naung Mung is inaccessible to trucks, elephants or pack animals. Nearly all interchange and wildlife trade between villages was, and still is, by means of narrow footpaths (Kingdon-Ward, 1949; Smythies, 1949, 2001; S. Renner, pers. obs.).

A recent countrywide study of forest cover between 1990 and 2000 (Leimgruber et al., 2005) supports our observation of low deforestation, demonstrating that deforestation is concentrated in mangroves, dry forests, dry dipterocarp forests, and areas in closer proximity to major markets. Shifting cultivation is also affecting large areas in the Chin Hills and Nagaland. However, the Northern Forest Complex, along with forests of the Rakhine Yoma and of Tanintharyi Division (Tenasserim), is among the largest remaining intact forest tracts (although lowland forest in Tanintharyi Division is undergoing rapid conversion to oil palm plantation; Eames et al., 2005). Timber may be a resource for future economic exploitation in the region because there are large trees that could be suitable for economic use. However, the remoteness and inaccessibility of the area has so far prevented exploitation and, to our knowledge, data on suitable tree species have not been collected.

As the human population in the Northern Forest Complex appears to be relatively stable (S. Renner, pers. obs., based on information from school headmasters in Putao District and Naung Mung Township, and from hospitals in Putao and Naung Mung), new agricultural areas are probably not required. Migration is, however, occurring: Tibetans, who are Buddhist, appear to be leaving their villages in the extreme north of the region and moving across the border into Tibet (S. Renner, pers. obs.). The deserted villages are being repopulated by Christian Rawan (Rau-wan) from the south. Of 12 Tibetan villages present in the area in 1995, only the northernmost five are still populated by Tibetans (S. Renner, pers. obs., 2005). Many people, especially the young, are increasingly heading for Putao, Myitkyina and Yangon (Rangoon, the former capital). There was also an influx into Pangnamdim in 2004 because the government encouraged immigration to this village; it had $<50$ inhabitants in 2001 but had increased to 200 by March 2006 (S. Renner, pers. obs.).

\section{Biodiversity}

Scientific exploration of the Northern Forest Complex has been limited (Table 3). During British colonial times prior to 1948 a few biologists and colonial officers conducted expeditions and collected birds and plants in northern Burma (Stanford \& Mayr, 1940; Smith, 1943; Kingdon-Ward, 1949; Smythies, 1949, 1953, 2001). Most trips merely traversed the Northern Forest Complex in attempts to explore Yunnan, Assam or Tibet (e.g. Kingdon-Ward, 1949, 1960). The first attempts to assess the biodiversity of the region were made in the last decade of the 20th century when it became apparent that the region probably contained a considerable number of undescribed species (Myers et al., 2000; K.-L. Schuchmann, pers. comm., 2000; Rappole et al., 2005; Rappole et al., in press). It has also been suggested that the region is a neo-refuge (Nekola, 1999; Myers et al., 
Table 3 Biological expeditions to the Northern Forest Complex (NFC), with the year, collector or expedition, the region investigated and the research aim.

\begin{tabular}{|c|c|c|c|}
\hline Year(s) & Expedition sponsor and/or participants & Region $^{1}$ & Topic \\
\hline 1904-31 & G. Forrest & Yunnan & Plants, birds \\
\hline 1906 & Bee Bee $^{2}$ & Yunnan & Pheasants \\
\hline $1914-53$ & F.K. Kingdon-Ward (1930, 1938, 1949, 1960) & Tibet, Kachin State, NFC & Plants, birds \\
\hline $1919-26$ & R. Farrer & & Rhododendron spp. \\
\hline 1935 & $\begin{array}{l}\text { A.S. Vernay, C.S. Cutting (after Stanford \& Ticehurst, 1935, } \\
\text { 1938-1939; Ticehurst 1939) }\end{array}$ & NFC & Barking deer, shrews \\
\hline c. 1940 & H.C. Smith (1943) & NFC & Birds \\
\hline 1944-45, 1948 & B.E. Smythies $(1949,1953)$ & NFC & Birds \\
\hline 1981 & Kyaw Soe & NFC & Medicinal plants \\
\hline 1996 & Saw Tun Khing, A. Rabinowitz & Putao & Conservation \\
\hline 1997 & Wildlife Conservation Society & NFC & Biology \\
\hline 1998 & Wildlife Conservation Society & Naung Mung area & Biology \\
\hline 2001 & J.H. Rappole, S.C. Renner, Nay Myo Shwe & Hkakabo Razi National Park & Birds, bats \\
\hline 2001 & J. Slowinski & NFC & Herpetofauna \\
\hline 2004 & J.H. Rappole, S.C. Renner, Nay Myo Shwe & NFC & Birds, bats \\
\hline 2005 & S.C. Renner, Thein Aung, Myint Aung & NFC & Birds \\
\hline
\end{tabular}

${ }^{1}$ If the region is not the Northern Forest Complex the area was traversed or visited enroute.

${ }^{2}$ Name of local collector as indicated on labels of the National Museum of Natural History bird collection, Washington, DC, USA

2000; Rappole et al., in press), i.e. an area harbouring rare or threatened species. For example, BirdLife International (2001a,b) suggested that rufous-necked hornbill Aceros nipalensis, considered threatened or extinct throughout most of its historic range, may occur in the Northern Forest Complex, and we recorded at least 50 individuals between Nam Ti and Masa (Fig. 1). Many new species and subspecies have been described from the Northern Forest Complex, and especially the Hkakabo Razi region, since 1999. The leaf deer Muntiacus putaoensis was the first of several new species to be described (Rabinowitz et al., 1999), followed by a new species of catfish Clupisoma sp. (Ferraris, 2004), a monkey from north-east Assam, India (Trachypithecus geei; Srivastava et al., 2001), several new orchids from the Hkakabo Razi National Park (Saw Lwin, 1999), reptiles from the Northern Forest Complex/north-east India (Slowinski \& Wuster, 2000; Slowinski et al., 2001) and new bird species and subspecies (e.g. Jabouilleia naungmungensis, Rappole et al., 2005).

Brummitt \& Lughadha (2003) ranked the Indo-Burma region as one of the eight most important global biodiversity hotspots, and the information now available for the Hkakabo Razi region further supports this. We observed hoolock gibbons Bunipithecus hoolock in the temperate rainforest areas, where red pandas Ailurus fulgens (Choudhury, 2001), gaur Bos gaurus and leopards Panthera pardus are also known to occur and were reported by local hunters. Tigers Panthera tigris (Lynam, 2003) had been seen by local people until c. 1985 but not subsequently. Although working elephants Elephas maximus are established in Naung Mung they are not considered to occur naturally in the Northern Forest
Complex (Leimgruber \& Wemmer, 2004). Table 4 gives the known number of species of various taxonomic groups in the Northern Forest Complex and, for comparison, in the whole of Myanmar.

\section{Known threats}

We found the local people in the Hkakabo Razi National Park to be extremely poor, and generally lacking funds to travel to Putao, the nearest large town. The only available currency is wildlife (fur and meat). They use this to obtain commodities such as salt, which is lacking the Northern Forest Complex because of the high precipitation. Much of the travel that occurs through the region appears to be by families, merchants, priests or smugglers. The merchants and smugglers deliver wildlife and forest products from the forests to the market in Putao.

\section{Conservation}

Within the region there are no other protected areas with habitats similar to the Northern Forest Complex. The closest reserves are the Gao Li Gong Shan Nature Reserve in China, c. $200 \mathrm{~km}$ south-south-east of Putao, and the Mouling National Park in Assam, India, c. $300 \mathrm{~km}$ to the west of Putao. The Northern Forest Complex offers unique opportunities for biodiversity conservation because inhabited areas are limited and deforestation is low. However, there are plans to develop the region. The Hkakabo Razi National Park, established in 1996 based largely on advice from the Wildlife Conservation Society (Rabinowitz et al., 1999; Rabinowitz, 2003), includes mainly the higher elevations in northern Kachin 
Table 4 Number of species of various taxonomic groups occurring in the Northern Forest Complex and Myanmar.

\begin{tabular}{|c|c|c|c|c|}
\hline Group & $\begin{array}{l}\text { No. of species in } \\
\text { Northern Forest } \\
\text { Complex }\end{array}$ & Source & $\begin{array}{l}\text { Estimated no. of species } \\
\text { in Myanmar }\end{array}$ & Reference or source \\
\hline Birds & 152 & S.C. Renner, J.H. Rappole & $>1,000$ & Saw Lwin (1999) \\
\hline Mammals & 42 & S.C. Renner, Thein Aung & 300 & Saw Lwin (1999) \\
\hline Reptiles & 80 & Thein Aung & 360 & Slowinski \& Wuster (2000) \\
\hline Butterflies & 365 & Thein Aung & & \\
\hline Trees & 297 & Thein Aung & 1,347 & Myo Khin \& Sein Aung (1999) \\
\hline Bamboo & 13 & Thein Aung & 96 & Myanmar Forest Department \\
\hline Plants & 469 & Myanmar Forest Department & 4,757 & Myanmar Forest Department \\
\hline Medicinal plants & 22 & Thein Aung & & \\
\hline Orchids & 106 & Thein Aung & 841 & Kyaw Nyunt (2001) \\
\hline Rattan & 10 & Thein Aung & 36 & Saw Lwin (1999) \\
\hline
\end{tabular}

State (Fig. 1). The rainforests where most new species have been discovered, and where most of the unique aspects of the region's biodiversity are located (Rappole et al., 2005) are south and west of the current Park boundaries. These areas are probably more threatened than most of Hkakabo Razi National Park because of their close proximity to human populations and relative accessibility. The establishment of Hkakabo Razi National Park was an important step, but protection of the diverse forests of Naung Mung is required to ensure the integrity of the Northern Forest Complex ecosystems.

The Northern Forest Complex still comprises a large amount of relatively untouched habitat of types that are generally rare in South-east Asia. Important areas of these forests are not protected despite establishment of Hkakabo Razi National Park and Hpongkan Razi Wildlife Sanctuary. We consider the following steps to be crucial for the conservation of the area:

- Establish an additional sanctuary or extend the boundaries of the existing Hkakabo Razi National Park southwards to the Naung Mung/Nam Ti area and the surrounding forests.

- Reduce wildlife trade by addressing poverty; this could include encouraging ecotourism (traders are currently paid in wildlife products, mainly the fur of deer and small species of wild felids, and not in money or agricultural products).

- Carry out further surveys to establish a more complete biodiversity inventory.

- Demarcate the existing sanctuaries and establish an education centre to disseminate the purpose of the sanctuaries and encourage their acceptance by local people.

- Halt attempts to encourage people to immigrate into the Park, as has occurred in Pangnamdim.

The relevant authorities and NGOs are aware of our recommendations. The authorities of Hkakabo Razi
National Park have proposed an extension of the boundaries of the Park south to U-Ring-Ga and Mali Hka (Fig. 1), and have also begun processes to implement the existing Park boundaries (as drawn in Fig. 1) and to reduce wildlife trade to India and China by enforcing the national law. We are planning further research to examine the bird and mammal diversity of the Northern Forest Complex and neighbouring areas of high conservation interest.

\section{Acknowledgements}

We thank the Nature and Wildlife Conservation Division of the Union of Myanmar Forestry Department, and especially Director U Khin Maung Zaw, for permission to conduct the study (Myanmar Collection and Export Permit \# SI/4697/2004). SST was helpful with logistics during the trip in 2001. We thank U Aung Khin and Daw Thandar Kyi (Myanmar Gateway Tours) who organized the 2004 and 2005 trips. The Smithsonian Institution, Office of the Undersecretary for Science, provided support through the Abbott Fund. Additional support came from the Alexander Wetmore Fund, Bird Division, and US National Museum of Natural History, Smithsonian Institution, for which we thank curators G. Graves and S. Olson. The Smithsonian National Zoological Park Institutional Animal Care and Use Committee provided clearance for the research (Project \#\# 01-34, 06-27). We are grateful to all of our assistants, particularly U Kyaw Lin, U Tu Myint U, U A Jo, and U Myint Kyaw, and 76 other helpers. M. Fisher, J. Eames and an unknown reviewer gave valuable comments on several versions of the manuscript.

\section{References}

Achard, F., Eva, H.D., Stibig, H.-J., Mayaux, P., Gallego, J., Richards, T. \& Malingreau, J.-P. (2002) Determination of deforestation rates of the world's humid tropical forests. Science, 297, 999-1002. 
BirdLife International (2001a) Threatened Birds of Asia: the BirdLife International Red Data Book. Pink-headed Duck Rhodonessa caryophyllacea. BirdLife International, Cambridge, UK. http://www.rdb.or.id/ detailbird.php?id=73 [accessed 16 March 2005].

BirdLife International (2001b) Threatened Birds of Asia: The BirdLife International Red Data Book. Rufous-necked Hornbill Aceros nipalensis. BirdLife International, Cambridge, UK. http:/ / www.rdb.or.id/detailbird.php?id=136 [accessed 16 March 2005].

BirdLife International (2003) BirdLife's Online World Bird Database: The Site for Bird Conservation. Version 2.0. BirdLife International, Cambridge, UK [http://www.birdlife.org accessed 15 March 2005].

Brummitt, N. \& Lughadha, E.N. (2003) Biodiversity: where's hot and where's not. Conservation Biology, 17, 1442-1448.

Choudhury, A. (2001) An overview of the status and conservation of the red panda Ailurus fulgens in India, with reference to its global status. Oryx , 35, 250-259.

Cincotta, R.P., Wisnewski, J. \& Engelman, R. (2000) Human population in the biodiversity hotspots. Nature, 404, 990-992.

Conservation International (2004) Biodiversity Hotspots Revisited. Conservation International, Washington, DC, USA. http:// www.biodiversityhotspots.org/xp/Hotspots/resources/ maps.xml [accessed 18 March 2005].

Eames, J.C., Htin Hla, Leimgruber, P., Kelly, D., Sein Myo Aung, Saw Moses \& Saw Nyunt Tin (2005) The rediscovery of Gurney's pitta Pitta gurneyi in Myanmar. Bird Conservation International, 15, 3-6.

EOS Data Gateway (2005) NASA Earth Observing System Data Gateway. NASA, Washington, DC, USA. [http:// edcimswww.cr.usgs.gov/pub/imswelcome/ accessed 15 January 2005].

FAO (2003) State of the World's Forests 2003. Food and Agriculture Organization, Rome, Italy.

Ferraris, C.J. (2004) A new species of the Asian schilbid catfish genus Clupisoma from Myanmar, with redescription of Clupisoma prateri Hora (Osteichthyes: Siluriformes: Schilbidae). Zootaxa, 437, 1-10.

Gascon, C., Williamson, G.B. \& da Fonseca, G.A.B. (2000) Receding forest edges and vanishing reserves. Science, 288, 1356-1358.

Kingdon-Ward, F. (1930) Plant Hunting on the Edge of the World. Victor Ollancz, London, UK.

Kingdon-Ward, F. (1938) Plant Hunter's Paradise. MacMillan, New York, USA.

Kingdon-Ward, F. (1949) Burma's Icy Mountains. Jonathan Cape Publishers, London, UK.

Kingdon-Ward, F. (1960) Pilgrimage for Plants. G. Harrap, London, UK.

Kyaw Nyunt (2001) Wild Orchids of Northern Myanmar. Unpublished Report for the Myanmar Floriculturist's Association, Yangon, Myanmar.

Leimgruber, P., Christen, C.A. \& A. Laborderie (2005) The impact of Landsat satellite monitoring on conservation biology. Environmental Monitoring and Assessment, 106, 81-101.

Leimgruber, P., Gagnon, J.B., Wemmer, C., Kelly, D.S., Songer, M.A. \& Selig, E.R. (2003) Fragmentation of Asia's remaining wildlands: implications for Asian elephant conservation. Animal Conservation, 6, 347-359.

Leimgruber, P., Kelly, D.S., Steininger, M., Brunner, J., Müller, T. \& Songer, M.A. (2005) Forest cover change patterns in Myanmar (Burma) 1990-2000. Environmental Conservation, 32, 356-364.
Leimgruber, P. \& Wemmer, C. (2004) National Elephant Conservation Symposium and Workshop. Unpublished Report, Myanmar Forest Department and the U.S. Fish \& Wildlife Service, Front Royal, USA.

Lynam, A.J. (2003) A National Tiger Action Plan for the Union of Myanmar. Unpublished Report for the Wildlife Conservation Society, New York, USA.

Mayaux, P., Achard, F. \& Malingreau, J.-P. (1998) Global tropical forest area measurements derived from coarse resolution satellite imagery: a comparison with other approaches. Environmental Conservation, 25, 37-52.

Myers, N., Mittermeier, R.A., Mittermeier, C.G., da Fonseca, G.A.B. \& Kent, J. (2000) Biodiversity hotspots for conservation priorities. Nature, 403, 853-858.

Myo Khin \& Sein Aung (1999) Vegetation and Key Floristic Features of the Hkakabo Razi National Park. Proceedings of a Workshop for Regional Collaboration in Conservation of the Hkakabo Razi Mountain Ecosystem, October 25-28. Putao, Myanmar.

Nekola, J.C. (1999) Paleorefugia and neorefugia: the influences of colonization history on community pattern process. Ecology, 80, 2459-2473.

Rabinowitz, A. (2003) Beyond the Last Village: A Journey of Discovery in Asia's Forbidden Wilderness. Island Press, Princeton, USA.

Rabinowitz, A., Thein Myint, Saw Tun Khaing \& Rabinowitz, S. (1999) Description of the leaf deer (Muntiacus putaoensis), a new species of muntjac from northern Myanmar. Journal of Zoology, London, 249, 427-435.

Rappole, J.H., King, D.R. \& Leimgruber, P. (2000) Winter habitat and distribution of the endangered golden-cheeked warbler (Dendroica chrysoparia). Animal Conservation, 2, 45-49.

Rappole, J.H., Renner, S.C., Nay Myo Shwe, Myint Aung \& Thein Aung (in press) Ornithogeography of the eastern Himalayas and neighbouring Burmese hill country. Bonner Zoologische Monographien.

Rappole, J.H., Renner, S.C., Nay Myo Shew \& Sweet, P.R. (2005) A new species of Jabouilleia from the sub-Himalayan region of Myanmar. Auk, 122, 1064-1069.

Reich, P.B., Walters, M.B. \& Ellsworth, D.S. (1997) From tropics to tundra: global convergence in plant functioning. Proceedings of the National Academy of Sciences USA, 94, 13730-13734.

Riitters, K., Wickham, J., O’Neill, R., Jones, B. \& Smith, E. (2000) Global-scale patterns of forest fragmentation. Conservation Ecology, 4, 3 [http://www.consecol.org/vol4/iss2/art3/ accessed 20 March 2005].

Robson, G. (2000) A Field Guide to the Birds of South-east Asia. New Holland, London, UK.

Saw Lwin (1999) An Introduction to Myanmar Native Orchids of the Hkakabo Razi Area. Proceedings of a Workshop for Regional Collaboration in Conservation of the Hkakabo Razi Mountain Ecosystem, October 25-28. Putao, Myanmar.

Slowinski, J.B., Pawar, S.S., Htun Win, Thin Thin, Sai Wunna Gyi, San Lwin Oo \& Hla Tun (2001) A new Lycodon (Serpentes: Colubridae) from Northeast India and Myanmar (Burma). Proceedings of the California Academy of Sciences, 52, 397-405.

Slowinski, J.B. \& Wuster, W. (2000) A new cobra (Elapidae: Naja) from Myanmar (Burma). Herpetologica, 56, 257-270.

Smith, H.C. (1943) Notes on the Birds of Burma. Eigenverlag, London, UK.

Smythies, B.E. (1949) A reconnaissance of the N'Mai Hka Drainage, northern Burma. Ibis, 91, 627-648. 
Smythies, B.E. (1953) The Birds of Burma. 2nd edition. Oliver and Boyd, Edinburgh, UK.

Smythies, B.E. (2001) The Birds of Burma. Natural History Publications (Borneo), Kota Kinabalo, Malaysia.

Srivastava, A., Biswas, J., Das, J. \& Bujarbarua, P. (2001) Status and distribution of golden langurs (Trachypithecus geei) in Assam, India. American Journal of Primatology, 55, 15-23.

Stanford, J.K. \& Mayr, E. (1940-1941) The Vernay-Cutting expedition to northern Burma. Ibis, 14, 679-711, 56-105, 213-245, 353-378, 479-518.

Stanford, J.K. \& Ticehurst, C.B. (1935) Notes on some new or rarely recorded Burmese birds. Ibis, 13, 38-65, 249-279.

Stanford, J.K. \& Ticehurst, C.B. (1938-1939) On the birds of northern Burma. Ibis, 14, 65-102, 197-229, 391-428, 599-638, $1-45,211-258$.

Stattersfield, A.J., Crosby, M.J., Long, A.J. \& Wege, D.C. (1998) Endemic Bird Areas of the World: Priorities for Biodiversity Conservation. BirdLife International, Cambridge, UK.

Ticehurst, C.B. (1939) Additional information on northern Burmese birds. Ibis, 14, 768-770.

Tordoff, A.W., Eames, J.C., Eberhardt, K., Baltzer, M.C., Davidson, P., Ha Quy Quynh \& Tran Thanh Tung (2004) Investment Opportunities in Biodiversity Conservation by Civil Society in Myanmar. Unpublished Report for The Critical Ecosystem Partnership Fund, Arlington, USA.

Tucker, C.J., Grant, D.M. \& Dykstra, J. (2004) NASA's global orthorectified Landsat data set. Photogrammertric Engineering and Remote Sensing, 70, 313-323.

\section{Biographical Sketches}

Swen C. Renner has been involved in conservation biology, biodiversity research and biogeography of birds and mammals in Myanmar since 2001. His current research focuses on community structure and land use changes.

John H. Rappole has been involved in ecological research, especially bird and bird migration, in Myanmar since 1992 and has provided training for local conservationists and ecologists.

Peter Leimgruber has undertaken several surveys of elephants in Myanmar, Sri Lanka and Thailand and organized a project to map deforestation in Myanmar. He is also involved in the training of conservationists in Myanmar.

Daniel S. Kelly is involved in research on elephants in Myanmar and Kenya.

Nay Myo Shew, Thein Aung and Myint Aung are Wardens of the Chattin Wildlife Sanctuary, Hkakabo Razi National Park and Thamanti National Park, respectively, and have worked in Hkakabo Razi National Park since 1998. 